\title{
Implementation Handling of Children in Dealing With The Law in Polres Purworejo
}

\author{
Setio Raharjo ${ }^{1}$
}

Abstract. The purpose of this research is to investigate the implementation of the handling of children in conflict with the law in Polres Purworejo; 2) to know the constraints faced by police investigators in Polres Purworejo in performing their duties as investigator; and 3) to find solutions investigator in the face of constraints in the implementation of the handling of children in conflict with the law in Polres Purworejo. The method used in this research is empirical juridical approach or in other words the socio-juridical.Specifications research is descriptive. Data used in this study are primary data and secondary data. Methods of collecting data in this study using library study or library research. Analysis of the data used is qualitative data. The study states that 1) in order to organize the protection of women and children who are victims of crime and law enforcement against perpetrators, Unit Women and Children (PPA) Police have implemented procedures in accordance with the regulations stipulated in the mennangani children behadapan with the law; 2) there are two obstacles that arise in the implementation of minimum service standards in Women and Children Services Unit (PPA) Polres Purworejo, namely internal and external obstacles; 3 ) the efforts undertaken to overcome existing obstacles, including by conducting education and training for members of the PPA good Unit investigator, investigator helpers and staff who are in the PPA Unit to strengthen Human Resources.

Keywords: Investigation; Children; Conflict with the Law.

\section{Introduction}

Based on the complexity of the problems relating to the protection to be given to a child in conflict with the law, there must be efforts from various parties in order to save the nation. The police as the frontline in law enforcement has a responsibility that is large enough to synergize the duties and authority of the Police as it has been regulated in Act No. 2 of 2002 on the Indonesian National Police in dealing with children in conflict with the law, the police always must consider the condition of children is different from adults.Social action handling children in conflict with the law with the number and diverse forms, required the state's effort to establish the Act No. 11 of 2012 on the Criminal Justice System children in conflict with the law with the handling and special protection to children.

According to Pieter G. Hoefnagels, various problems arising child should be taken seriously with a view to restore order in society. Combating crime social action must be an integral child for child crime issues as the next generation of national struggle is a matter of humanity. Approach only through the application of criminal law is not merely the right, because the application of criminal law has limits. ${ }^{2}$ Criminal law sanctions is used for this is not a cure to eradicate the source of the disease (evil), but just dealing with the symptoms

\footnotetext{
1 Student of Masters (S2) of Law Faculty of Law Unissula and Police Member Officer email: unitrenaktapolrespwr@gmail.com

${ }^{2}$ Barda Nawawi Arief 1998 Beberapa Aspek Kebijakan Penegakan dan. Pengembangan Hukum Pidana Citra Aditya Bakti Bandung p. 44-45.
} 
or disease, so that children become recidivist offenders and the community act mimics crime. This is due to the application of criminal witness can not see the root of the problem which is a problem that causes children to commit crimes. Therefore, we need a new thinking to the social approach in addition to the application of criminal sanctions against children in conflict with the law.

In everyday life, there is no doubt that the growing modernization of all spheres of life, growing anyway crimes and little crimes involving children under age either as victims, witnesses or perpetrators of such instances occurring in several regions Purworejo. A child protection case data handled by Polres Purworejo Unit IV Period of 2017-2018.

Table 1

Data Case Police Child Protection Unit IV Purworejo 2017-2018

\begin{tabular}{|c|l|c|c|c|}
\hline \multirow{2}{*}{ No. } & \multirow{2}{*}{ Case } & \multicolumn{2}{|c|}{ Year } & \multirow{2}{*}{ Amount } \\
\cline { 3 - 4 } & & 2017 & 2018 & \\
\hline 1 & Obscene Acts & 4 & 6 & 10 \\
\hline 2 & Child Sexual Intercourse & 2 & 7 & 9 \\
\hline & Amount & 6 & 13 & 19 \\
\hline
\end{tabular}

Based on the table it is clear that every year a child protection cases handled by the Polres Purworejo IV units continues to increase where in 2017 the unit IV Polres Purworejo handle as much as 6 cases: 4 cases of obscene acts and two cases of child sexual intercourse. The case was increased in the year 2018 as many as 13 cases, of which 6 cases of obscene acts and 7 obscene acts. In addition, in the handling of data can be seen in the following table.

Table 2

Women and Children Case Data 2016-2018

\begin{tabular}{|c|l|c|c|c|c|c|c|}
\hline \multirow{2}{*}{ No. } & \multirow{2}{*}{ Case } & \multicolumn{2}{|c|}{2016} & \multicolumn{2}{c|}{2017} & \multicolumn{2}{c|}{2018} \\
\cline { 3 - 8 } & & $\mathrm{CT}$ & $\mathrm{CC}$ & $\mathrm{CT}$ & $\mathrm{CC}$ & $\mathrm{CT}$ & $\mathrm{CC}$ \\
\hline 1 & Molestation & 3 & 3 & 4 & 3 & - & - \\
\hline 2 & Intercourse & 22 & 20 & 7 & 6 & 3 & 3 \\
\hline 3 & Adultery & - & - & 1 & 1 & 1 & 1 \\
\hline & amount & 25 & 23 & 12 & 10 & 4 & 4 \\
\hline
\end{tabular}

Source: Unit IV Polres Purworejo

The above table states that the handling of cases of sexual intercourse more dominant in Polres Purworejo and the perpetrator or the victim is under the age of majority, it is clear that the Police to take immediate action in this case is the investigation it is apparent number of cases resolved by Unit IV Polres Purworejo.

Dealing with Crime Children following are examples of cases found in the Polres Purworejo namely Docket No. BP / / XII / 2017 / Reskrim has happened crimes of violence against children committed in the village of Bener District of Purworejo conducted by Arif Bhekti Tri Cahyadi and Fayet Kurnia against Mutakin. Arif and Fayet commit criminal acts of violence, by Arif piggybacking Fayet using Honda Beat motorcycle belonging to Arif then Fayet slashing back Mutakin using sembilah celurit brought Fayet using his left hand, as a result of the incident Mutakin injured stabbed in the back and treated at home pain and reported the incident at the police station Purworejo. 
While on the Docket Number: BP / 28 / IV / 2018 / Reskrim shows that there has been a criminal act of intercourse against children occurs first January 9, 2018 the last on March 22, 2018 in the home of Uncle Arief done by children Arief against children Alinda manner Alinda seduce and say that "turon kene", then Alinda lie down and kiss on the cheek and lip Arief Alinda. Additionally, Arief invite Alinda to have intercourse with her. Additionally, Arief when he will be responsible for his actions against Alinda. The problem based Arief alleged to have committed the crime of sexual intercourse against children as referred to in Article 81 of Act No. 35 of 2014 regarding amendments by Act No. 23 No. 2002 on the protection of children.

Based on these facts, the author aims to conduct research with the title "Implementation Treatment of Children against the Law On Polres Purworejo". To lead to the subject matter, the author tries to formulate the problem as follows:1) how the implementation of the handling of children in conflict with the law in Polres Purworejo?; 2) What obstacles faced Polres Purworejo investigators at the police station in his duties as an investigator?; and 3) How investigators solution in the face of constraints in the implementation of the handling of children in conflict with the law in Polres Purworejo ?.

\section{Research Methods}

The method used in this research is empirical juridical approach or in other words the socio-juridical. Juridical empirical approach is emphasizing research aimed at obtaining legal knowledge empirically by the way go directly to the object ${ }^{3}$,Specifications research is descriptive, because that it specifically, this study aims to describe the problem in this research. ${ }^{4}$ Data used in this study are primary data and secondary data. Methods of collecting materials is done by library research and interviews with Police PPA Unit Purworejo Data analysis is the process of organizing the data so that the data can be interpreted. ${ }^{5}$ In this case the analysis of qualitative data is data which can not be measured or judged by the numbers directly. ${ }^{6}$

\section{Results and Discussion}

\subsection{Handling Implementation of Children against the Law On Polres Purworejo}

The results showed that in practice that occurred over the years, efforts to resolve the problem of children in conflict with the law is carried out through the efforts of diversion and restorative Justice, but also found a child who was arrested for his actions, but the laws of Juvenile Justice has provided legal guarantees for the child, that the child court held separately from adults. Juvenile justice only for children involved in criminal cases.

The children in conflict handling mechanisms in Police Puworejo law, starting with the legal process facing children on the level of inquiry and investigation. It begins the process of arrest by the police, both were caught and reported by victims. This process into the entrance of children undergoing further legal process. The process of handling children undergoing legal process is performed on Women and Children Service Unit (PPA). This unit is in charge of providing services for Children in Conflict with the Law on Polres

\footnotetext{
${ }^{3}$ Soerjono Soekanto. 2007 Pengantar Penelitian Hukum UI Press Jakarta p. 51.

${ }^{4}$ Ibid. p. 42.

${ }^{5}$ Dadang Kahmad 2000 Metode Penelitian Agama CV Pustaka Setia Bandung p. 102.

${ }^{6}$ Tatang M. Aminrin 1995 Menyusun Rencana Penelitian PT. Raja Grafindo Persada Jakarta p. 134.
} 
Purworejo protection of women and children who are victims of crime and law enforcement against the perpetrators.

Duties of Unit PPA is receiving reports and complaints, conducting investigations and inquiries, ask for a post mortem and work for vise et Psikiatrum, identifying the needs of the child as a child as a suspect include requesting assistance both legal and social, counseling / psychosocial therapy, supervise and coordinate with various parties and providing information services.

Children in conflict with the law must go through the investigation procedure as follows:

- Rapporteur or complaints should be forwarded or received in Unit PPA

- PPA Unit officers follow and process complaints / reporting

- Unit PPA appoint investigators or some investigators adjusted for case and gender of the child

- Before the arrest (child term used to arrest is calling) investigators first examine the complainant and the witnesses included consultations with expert witnesses

- If efforts calling / arrest should be done by buser / serse outdoor unit of Unit PPA or at least by buser with the perspective of a child

- Catching or calling the child should also consider psychological or other effects on children

- Children who are arrested or summoned should be directed towards RPK or PPA Unit

- Initial examinations of children should pay attention to the condition and readiness of the child as well as examination time (interview)

- Before the examination (interview) took place, investigators must consider and prepare the following: 1) to prepare equipment and supplies, including for example the food, beverage, and others; 2 ) conditioning the examination comfortable place for children; 3) contacting the interested parties to the investigation process (family, child companion, Bapas, victims or their families, attorneys / paralegals, a friend of the child); 4) investigators conduct preliminary interviews with the child to get an assessment of the child and the case; 5) provides the opportunity for the family, Bapas, escort the child or legal counsel to meet and conduct interviews with children; 6) request the results of interim assessments of children to Bapas; 7) investigators take further action, diversion investigation; 8) if done diversi the investigator take steps versioned with the parties to make a statement which is known by the investigator diversion parents / guardians of the perpetrator, the victim, and community leaders; 9) if the diversion can not be done, then the investigator to continue the investigation with reference to the best interests of children and pay attention to their rights.

\subsection{Obstacles Faced Police Investigator Polres Purworejo Undertaking In His job as investigator}

Constraints in handling children in conflict with the law consists of:

\subsubsection{The internal resistance}

Internal barriers are barriers that come from the PPA Police Unit itself. These barriers include the control of the investigator in mastering the techniques of investigation, less patience, less communicative and slow service in the reception report. Handling children in conflict with the law is different with handling procedures adults who commit criminal acts at the level of investigation. Therefore, in the Juvenile Justice Act and the Decree of 
the Chief of Police of the requirements to become a child investigator is investigating a child is a member of the national police that has been experienced in the investigation of adults and has an interest, dedication and understanding the problems of children. Under these provisions in mind that not all investigators can be a child investigator.

Associated with the experience of the investigator as investigator children is important. In the investigation of children an investigator must master the technique of investigation is an investigation procedure or mechanism to be set and in the case of the investigation of the child then the child must master teknil investigator investigation is a standard procedure of investigation that must be mastered. However the investigators in the Unit PPA are not all able to master the technique of investigation of the child as well.

Besides the lack of mastery of the techniques of investigation, investigators at Unit PPA also admit that they lack patience in dealing with cases brat. The probe requires patience especially on examination of juvenile delinquents. This is because the bad boy had a mental and spiritual state that is different from adults. Therefore, to persuade children to tell the truth is very difficult if there is no patience in self PPA Unit staff.

Communicative in examinations is very important also because this will facilitate the investigator in conducting the examination. Party Unit IV PPA Polres Purworejo admit that the number of staff who mostly have experience in communicating properly with the bad boy. This is one of the obstacles in the application of minimum service standards for children because communicative is one form of this standard in the examination in the unit PPA.

\subsubsection{External barriers}

External obstacles in the treatment of children in conflict with the law suffered Unit PPA Polres Purworejo is unknown parents / guardians relating to criminal offenses committed by their children so that it can hinder the process of law enforcement and training for children in conflict with the law in UPPA Polres Purworejo against naughty children. The result is a parent as a party that is closest to the naughty children in the life of a day can not report or complain about their children as perpetrators of criminal acts to the police the next if they are arrested, they will be processed by the Unit PPA.

\subsection{Investigators Solutions Facing Obstacles in Implementing Management of Children against the Law On Polres Purworejo}

Efforts are being made to overcome the obstacles in handling children in conflict with the law is to conduct education and training for members of the PPA good Unit investigator, investigator aides and staff who are in the PPA Unit to strengthen Human Resources. Education and training is given in the form of training and education on investigative techniques pengusasaan based working procedures in accordance with existing regulations. The staff there were sent to the Mabespolri in order to obtain specialized education and training in the examination of children in conflict with the law should be in accordance with the specified standard.

In addition, seminars and workshops are also carried out by the Polres Purworejo both funded by the Government and funded by international organizations who are concerned about the problems of children, including children in conflict with the law, such as UNICEF. The staff involved actively in seminars and workshops in the hope that they know how to deal with children in conflict with the law, respect for their human rights as well as 
expected with the participation of the staff Unit PPA they have the dedication and better attention to children as perpetrators of crime. Almost at least 1 month they carry Seminars and workshops relating to children as perpetrators of crime.

Cooperation and coordination with related intstansi and the dissemination of their existence PPA Police Unit Purworejo through the media and stakeholders such as Local Government and Institutions that care for the child. Handling children in conflict with the law at every level of examination involves such a special officer of Advisors / Counselors Kmenterian Society of Law and Human Rights, Social Worker at the Department of Social Welfare and NGOs with special attention to the handling of children.

\section{Closing}

\subsection{Conclusion}

The conclusion of this study as follows:

- In order to provide protection to women and children who are victims of crime and law enforcement against perpetrators, Women and Children Service Unit (PPA) Police have implemented procedures in accordance with the regulations stipulated in the mennangani children behadapan with the law;

- There are two obstacles that arise in the implementation of minimum service standards in Women and Children Services Unit (PPA) Polres Purworejo, namely internal and external obstacles;

- The efforts undertaken to overcome existing obstacles, including by conducting education and training for members of the PPA good Unit investigator, investigator helpers and staff who are in the PPA Unit to strengthen Human Resources.

\subsection{Suggestion}

Investigator who has been educated and trained at the Unit of Women and Children Polres Purworejo should not be moved to the section or other units, in addition to the expected handling of children in conflict with the law should in the future be adapted to the law courts new child namely Act 11 of 2012 on Juvenile Justice System.

\subsection{References}

[1] Act No. 11 of 2012 on Child Criminal Justice System

[2] Act No. 2 of 2002 on the Indonesian National Police

[3] Act No. 23 of 2002 on Child Protection

[4] Barda Nawawi Arief 1998 Beberapa Aspek Kebijakan Penegakan dan. Pengembangan Hukum Pidana Citra Aditya Bakti Bandung.

[5] Civil Code

[6] Constitution of the Republic of Indonesia of 1945

[7] Dadang Kahmad 2000 Metode Penelitian Agama CV Pustaka Setia Bandung.

[8] Penal Code

[9] Ronny Hanitijo 1990 Metodelogi Penelitian Hukum dan Jurimetri Ghalia Indonesia Jakarta.

[10] Soerjono Soekanto. 2007 Pengantar Penelitian Hukum UI Press Jakarta.

[11] Tatang M. Aminrin 1995 Menyusun Rencana Penelitian PT. Raja Grafindo Persada Jakarta. 
Jurnal Daulat Hukum

Volume 1 No. 2 June 2018

ISSN: 2614-560X
Implementation Handling of Children in Dealing...

(Setio Raharjo) 